\title{
Molecular Modeling Study of 2-Substituted Isoindoline Derivatives of $\alpha$-Amino Acids as Inhibitors of Lipoxygenase by Docking Simulations
}

\author{
Teresa Mancilla Percino, ${ }^{* 1}$ José Correa Basurto, $, 23,4$ Karla S. Alavés Carbajal, ${ }^{2}$ Nagchielli Valle-Sandoval, ${ }^{2}$ \\ and José Trujillo Ferrara ${ }^{2,3,4}$ \\ ${ }^{1}$ Centro de Investigación y de Estudios Avanzados del Instituto Politécnico Nacional, Departamento de Química. Apartado Postal \\ 14-740, CP 07000, México, D. F. México.tmancill@cinvestav.mx \\ ${ }^{2}$ Instituto Politécnico Nacional, Escuela Superior de Medicina, Sección de Estudios de Posgrado e Investigación \\ ${ }^{3}$ Departamento de Bioquímica, ${ }^{4}$ Departamento de Farmacología. Plan de San Luis y Díaz Mirón s/n Col. Casco de Santo Tomás, \\ Delegación Miguel Hidalgo, C. P. 11340, México, D. F.
}

Received October 24, 2008; accepted January 23, 2009

\begin{abstract}
In this work two series of isoindolines 1(a-g) and 2(a-g) were evaluated as possible inhibitors of lipoxygenase (LOX) by docking studies, as well as for the antiinflammatories isoindolilamides 3-5 and ibuprofen 6, as part of a theoretical study to found dual LOX/ COX inhibitory activities. Therefore, dihydrodimethylbenzofurane 7 , licofelone 8 and darbufelone $\mathbf{9}$ were also evaluated, which are wellknown as dual LOX/COX inhibitors and consequently, in this work they were used to identify their binding sites on the LOX and compared with those obtained from 1(a-g), 2(a-g) and $\mathbf{3}$ to $\mathbf{6}$ under study. Analysis of the results showed that all compounds under study could inhibit to the LOX, since they are binding in the same or close to the region as the compounds 7-9 taken as references. Several interactions of heteroatom of all compounds with the amino acid residues of binding sites of LOX were determined. The $\Delta \mathrm{G}$ values were obtained for all the complexes (LOX-compound), among all the complexes, LOX-8 $(-12.76 \mathrm{kcal} / \mathrm{mol})$ resulted to be the most stable; and from the compounds under study, LOX-1f $(-8.97 \mathrm{kcal} / \mathrm{mol})$ resulted to be more stable than the other compounds tested. Whereas, theoretical dissociation constant values $K_{d}(\mu \mathrm{M})$ were obtained. Among all compounds, $8(0.000433 \mu \mathrm{M})$ showed more affinity to LOX; while from compounds under study, 1f $(0.266 \mu \mathrm{M})$ exhibited more affinity to LOX. These results also show that compounds $\mathbf{1}(\mathbf{a}-\mathbf{g})$ and $\mathbf{2}(\mathbf{a}-\mathbf{g})$, and 3-6 could have a dual LOX/COX/ inhibition, as have been shown for 7-9 and from their similar docking study within the COX-1 and COX-2 previously reported.
\end{abstract}

Key words: Lipoxygenase, Docking, Isoindolines, Antiinflamatory, Analgesic, $\alpha$-Amino acids.

\section{Introduction}

The pain is the main cause of medical attention and also, it is a symptom of some diseases defined as "unlikable sensitive and emotional experience, related with real or potential tissue damage" [1]. It is known that ciclooxygenases (COX-1 and -2) and lipoxygenase (LOX) are involved in the metabolism of arachidonic acid generating eicosanoids, which have been implicated in the pathogenesis of a variety of human diseases [2]. It is established that conventional nonsteroidal antiinflammatory drugs (NSAIDs) and selective COX-2 inhibitors decrease the bioconversion of arachidonic acid to pro inflammatory prostaglandins (PGs) by inhibiting the COX catalytic activity [3]. In spite of COX-2 inhibitors have showed to have more effective
Resumen. En este trabajo se evaluaron dos series de isoindolinas $\mathbf{1}(\mathbf{a}-\mathbf{g})$ y $\mathbf{2}(\mathbf{a}-\mathbf{g})$ como posibles inhibidores de lipoxigenasa (LOX) por estudios docking, así como para los antiinflamatorios isoindolilamides 3-5 e ibuprofeno 6, como parte de un estudio para encontrar actividades inhibitorias duales LOX/COX. Además, también fueron evaluados dihidrodimetilbenzofurano 7, licofelona 8 y darbufelona $\mathbf{9}$, los cuales son bien conocidos como inhibidores duales LOX/COX y consecuentemente, en este trabajo fueron usados para identificar sus sitios de enlazamiento sobre la LOX y comparados con aquellos obtenidos de los compuestos bajo estudio $\mathbf{1}(\mathbf{a}-\mathbf{g}), 2(\mathbf{a}-\mathbf{g})$ y $\mathbf{3}$ a $\mathbf{6}$. El análisis de los resultados muestra que los compuestos bajo estudio podrían inhibir a la LOX, dado que actúan en la misma región o cerca que los compuestos 7-9 usados como referencia. Se determinaron algunas interacciones de los heteroátomos de todos los compuestos con los residuos de los aminoácidos de los sitios activos de LOX. Se obtuvieron los valores de $\Delta \mathrm{G}$ para todos los complejos (LOX-compuestos), entre todos los complejos, LOX-8 $(-12.76 \mathrm{kcal} / \mathrm{mol})$ resultó ser el más estable; y de los compuestos bajo estudio, LOX-1f $(-8.97 \mathrm{kcal} / \mathrm{mol})$ resultó ser más estable que los otros compuestos probados. Además, se obtuvieron los valores de las constantes de disociación teórica $K_{d}$ $(\mu \mathrm{M})$. Entre todos los compuestos, $8(0.000433 \mu \mathrm{M})$ mostró mayor afinidad a la LOX; mientras que de los compuestos bajo estudio, $\mathbf{1 f}$ $(0.266 \mu \mathrm{M})$ exhibió mayor afinidad a la LOX. Estos resultados muestran que los compuestos $\mathbf{1}(\mathbf{a}-\mathbf{g}), \mathbf{2}(\mathbf{a}-\mathbf{g})$ y $\mathbf{3}$ a $\mathbf{6}$ podrían tener inhibición LOX/COX dual como ha sido mostrado por 7-9 y del estudio similar docking en COX-1 y COX-2 previamente reportado.

Palabras claves: Lipoxigenasa, Docking, isoindolinas, antiinflamatorio, analgésico, $\alpha$-Aminoácidos.

anti-inflammatory properties than classical NSAIDs, still they are not totally safe, due to the implication of COX-2 in several physiological functions; for instance, renal homeostasis, in different stage of pregnancy, in the protection of the gastric mucosa, as well as in the cardiovascular system [4-7]. On the other hand, it is known that leukotrienes and lipoxins produced via the LOX pathway, play role in inflammation and promote the development of gastrointestinal tract $[4,8,9]$. Moreover, expression of LOX and the presence of their products are associated with immune, proliferative diseases, inflammatory bowel diseases, psoriasis, asthma, allergic, inflammatory disorders, cochlear acoustic injury, atherosclerosis and osteoporosis [2,10-19]. Thus, it has been considered that the inflammation is a multifactorial process and biochemical pathways 
should be taken into account, including the LOX pathway [8]. In consequence, drugs able to block COX and LOX pathway (drugs inhibitors) have been developed and pharmacologically investigated, which, should not only present a superior antiinflammatory profile but also fewer side effects than NSAIDs and selective COX-2 inhibitors [2, 4, 8, 9, 11, 13, 20-28]. On the other hand, we have been interested in the biological activities of isoindolines, various of them have been important as intermediates for the syntheses of novel multidrugs resistance reversal agents [29]. They have also shown diuretic activity $[30,31]$, as well as used for treating coronary vessel diseases and evaluated as alpha-adrenergic and adrenergic neuron blocking agents [32-34]. Therefore, several isoindolines have exhibited anti-inflammatory $[35,36]$ and analgesic activity $[36$, 37]. Our interest in the synthesis [38] and biological application of isoindoline derivatives of $\alpha$-amino acids, we have recently reported the theoretical study as COX-1 and COX2 inhibition as well as inhibitors in vitro [39,40]. Thus, we attempt a theoretical study of isoindolines $\mathbf{1}(\mathbf{a}-\mathbf{g})$ and $\mathbf{2}(\mathbf{a}-\mathbf{g})$ by docking, as well as for isoindolilamides 3-5 and ibuprofen 6 as part of a theoretical study to found dual LOX/COX inhibitors. Therefore, dihydrodimethylbenzofurane 7 [26], licofelone 8 [14, 15, 27] and darbufelone 9 [9] were also evaluated, which have showed dual 5-LOX/COX inhibition and in this work they were used to identify the active sites on the 15-LOX and compared with those obtained from $\mathbf{1}(\mathbf{a}-\mathbf{g})$, 2(a-g) and 3-6.

\section{Result and discussion}

Molecular modeling (docking) study was carried out for two series of isoindolines $\mathbf{1}(\mathbf{a}-\mathbf{g}), \mathbf{2}(\mathbf{a}-\mathbf{g})$, (Fig.1), as well as for isoindolilamides 3-5, ibuprofen 6 (Fig. 2) and also for dihydrodimethylbenzofuran $\mathbf{7}$, licofelone $\mathbf{8}$, and darbufelone 9 (Fig. 3). The results show that both isoindolines $\mathbf{1}(\mathbf{a}-\mathbf{g})$ and $\mathbf{2}(\mathbf{a}-\mathbf{g})$ series, as well as compounds 3-9 bind within LOX.

Compounds 1c, 1d, 1e, 1g, 2c, 2d, 2f, 2g, 5, and 6, as well as compounds 7-9 taken as references, binding within LOX in the vicinity of the amino acid residues 96-168 ( $\beta$-barrel domain) and amino acid residues 377-396, (Fig. 4, Tables 1 and 2), which are part of catalytic domain (360-366 and 537-543 residues); whereas this domain is characterized for containing the residues His $361,366,541$, and 545 , and they are coordinated to the non-haem catalytic iron [10]. Due to compounds 1c, 1d, 1e, 1g, 2c, 2d, 2f, 2g, 5 and $\mathbf{6}$ are binding to the LOX at the same region that compounds taken as reference; this indicates that these compounds could be LOX inhibitors.

The compounds $\mathbf{1 a}, \mathbf{1 b}, \mathbf{1 f}, \mathbf{2 a}, \mathbf{2 b}$ and $\mathbf{4}$ are binding to LOX in the region of the core of the catalytic domain (360-366 and 537-543 residues), (Table 3). Although these compounds are not binding within to LOX exactly at the same region as compounds $\mathbf{7}$ to $\mathbf{9}$, they can be considered as feasible LOX inhibitors due they are within the catalytic domain.
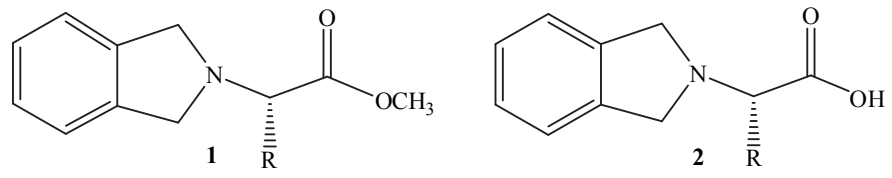

1a, 2a: $\mathrm{R}=\mathrm{H}$

1b, 2b: $\mathrm{R}=\left(\mathrm{CH}_{3}\right)_{2} \mathrm{CHCH}_{2}$

1c, $2 \mathrm{c}: \mathrm{R}=\mathrm{CH}_{3} \mathrm{CH}_{2}\left(\mathrm{CH}_{3}\right) \mathrm{CH}$

1d, 2 d: $\mathrm{R}=\mathrm{CH}_{3} \mathrm{SCH}_{2} \mathrm{CH}_{2}$

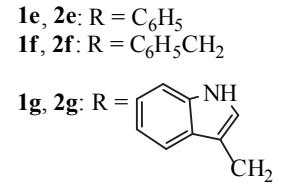

Fig. 1. Isoindolines series $\mathbf{1}(\mathbf{a}-\mathbf{g})$ and $\mathbf{2}(\mathbf{a}-\mathbf{g})$.<smiles>NC(=O)CN1Cc2ccccc2C1</smiles>

3

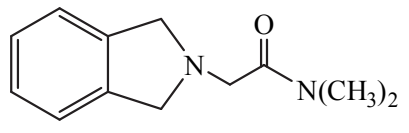

5<smiles>CNC(=O)CN1Cc2ccccc2C1</smiles>

4<smiles>CC(C)Cc1ccc([C@H](C)C(=O)O)cc1</smiles>

Fig. 2. Isoindolilamides 3, 4, 5, and ibuprofen $\mathbf{6}$.

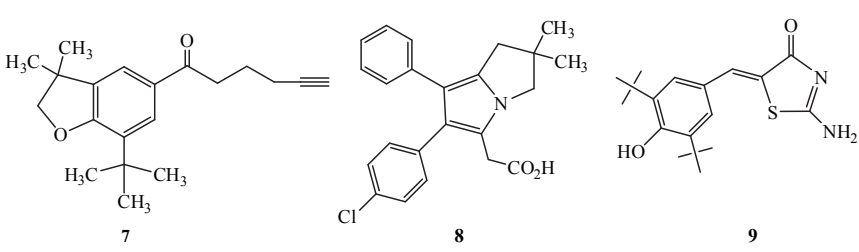

Fig. 3. Dihydrodimethylbenzofuran 7, licofelone 8 and darbufelone 9.

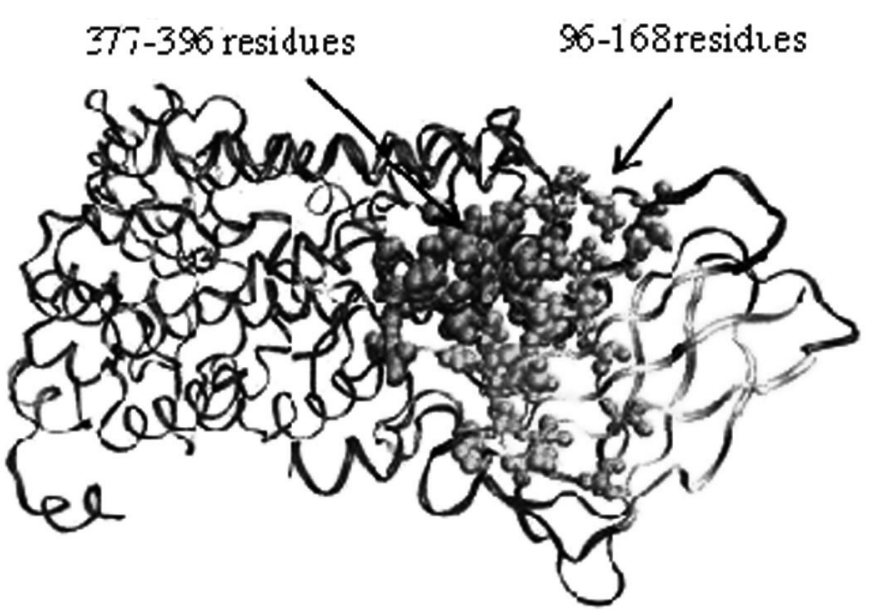

Fig. 4. Docking 1c, 1d, 1e, 2c, 2d, 2f, 2 g and 5 to 9 (ball) in LOX site (ribbon). 
Table 1. Compounds 1c-e, 1g, 2c-d, 2f-g and 5 to 9 within of LOX $\beta$-barrel domain.

LOX's amino acid residues

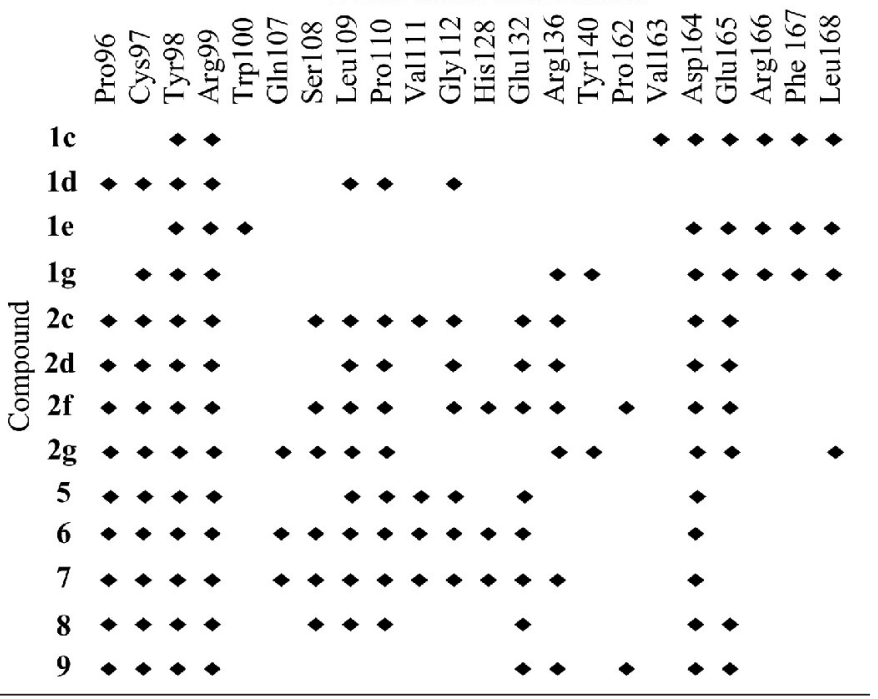

Table 2. Compounds 1c-e, 1g, 2c-d, 2f-g and 5 to 9 within of LOX catalytic domain.

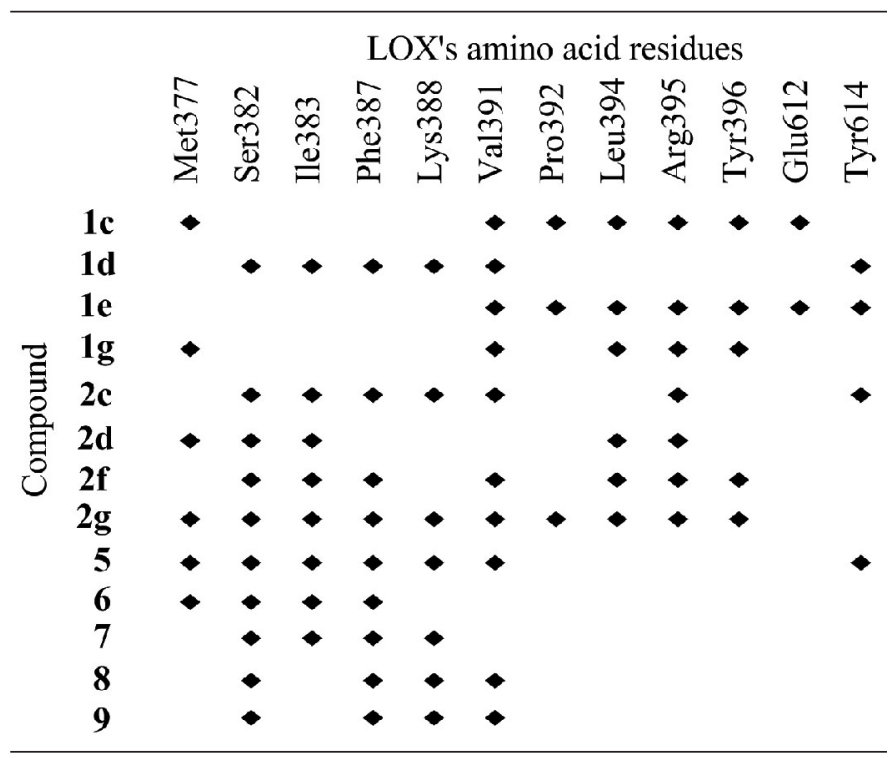

Table 3. Compounds 1a, 1b, 1f, 2a, 2 b and 4 within of LOX catalytic domain.

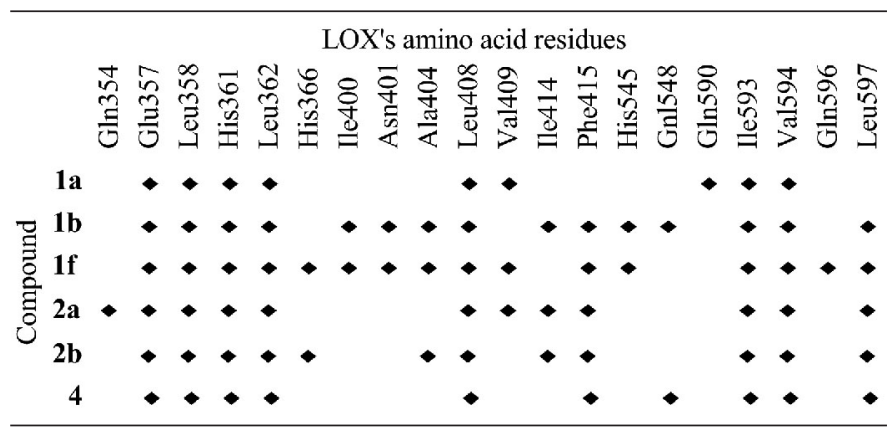

While compounds $\mathbf{2 e}$ and $\mathbf{3}$ are binding to the LOX among amino acids residues near to catalytic iron atom, 3 also binds in the vicinity of catalytic domain (Table 4). These results also reveal that these compounds could also inhibit to LOX.

An analysis of the near distances between atoms of amino acids residues of LOX with heteroatoms, carbons or protons of isoindolines $\mathbf{1}(\mathbf{a}-\mathbf{g})$ and $\mathbf{2}(\mathbf{a}-\mathbf{g})$, as well as those of the compounds 3 to 9 was carried out with the aim to investigate the binding mode for LOX. Thus, the selected distances are in agreement to those with similar or shorter than the sum of van der Waals radius for atoms and hydrogen bond lengths found in proteins [41]. Thus compounds 5, 7, 8 and 9 exhibit the following distances: $4.21 \AA$ between a methyl group of $\mathrm{N}\left(\mathrm{CH}_{3}\right)_{2}$ of 5 with backbone $\mathrm{O}$ of Pro96; $2.88 \AA$ between $\mathrm{C}=\mathrm{O}$ group of 7 with backbone oxygen of $\mathrm{C}=\mathrm{O}$ of Pro 96 ; $3.08 \AA$ between $\mathrm{HO}$ group of $\mathbf{8}$ and side chain $\mathrm{CB}$ of Pro96 and $2.82 \AA$ involving N1 of 9 with backbone O Pro96. The distance from backbone $\mathrm{O}$ of Cys97 to $\mathrm{N}$ atom of $\mathbf{1 d}, \mathbf{2 c}$ and 2d is of $2.90 \AA, 3.23 \AA$ and $3.24 \AA$, respectively. The $\mathrm{OH}$ and $\mathrm{N}$ of $\mathbf{2} \mathbf{f}$ interact with side chain $\mathrm{NH}_{2}$ and $\mathrm{N}$ of Arg99 showing a distance of $2.27 \AA$ and $3.04 \AA$ respectively. Compound $\mathbf{2 g}$ shows interaction of The $\mathrm{C}=\mathrm{O}$ group of $\mathbf{2} \mathbf{g}$ exhibits a distance of $3.32 \AA$ with side chain $\mathrm{N}$ of Arg99. The distance between $\mathrm{C}=\mathrm{O}$ group of $\mathbf{1 d}$ with side chain $\mathrm{C}$ of Leu109 is of $3.21 \AA$. The HO group of $\mathbf{2} \mathbf{f}$ shows a distance of $2.83 \AA$ with backbone $\mathrm{O}$ of Leu109. The $\mathrm{OH}$ group of $\mathbf{6}$ exhibits hydrogen interaction of with backbone $\mathrm{O}$ of Val111 with a distance of $2.21 \AA$. The $\mathrm{OH}$ group of $\mathbf{2 g}$ interacts with side chain $\mathrm{NH}_{2}$ of $\mathrm{Arg} 136$ $(1.88 \AA)$. The $\mathrm{O}$ atom (furan ring) of 7 interacts with backbone with side chain $\mathrm{N}$ of $\operatorname{Arg} 136$ (3.58 Å). Compound $\mathbf{1 g}$ undergoes the following interactions, $\mathrm{HN}$ with backbone $\mathrm{O}$ of Asp164 (3.08 $\AA$ ) and NH with backbone O of Glu165 (2.67 $\AA$ ). The distance between $\mathrm{CH}_{3}$ group of compound $\mathbf{1 e}$ and backbone $\mathrm{C}=\mathrm{O}$ of $\mathrm{Arg} 166$ is $3.21 \AA$. The atoms of compounds 1a, 2a and $\mathbf{4}$ display the following distances: $3.12 \AA$ between $\mathrm{N}$ atom of 1a and side chain $\mathrm{C}=\mathrm{O}$ of Glu357; $\mathrm{N}$ atom of compound 2 a shows distance of $3.10 \AA$ and $2.06 \AA$ with side chain $\mathrm{OE}$ and $\mathrm{OH}$ groups and with backbone $\mathrm{O}$ of Glu357, respectively. Nitrogen atom of 4 shows a distance of $3.42 \AA$ with side lateral OE2 of Glu357. Oxygen and carbon atoms of $\mathrm{C}=\mathrm{O}$ and $\mathrm{OCH}_{3}$ groups of $1 \mathbf{a}$, exhibit distances of 3.57 and $2.79 \AA$ with side chain CD1 and CD2 of Leu362, respectively. Methyl group of $\mathbf{1 g}$ shows a distance of $3.06 \AA$ with side chain $\mathrm{C}$ of Thr373. Carbonyl group of 2c exhibits a distance

Table 4. Compounds $2 \mathrm{e}$ and $\mathbf{3}$ within of LOX near to catalytic iron atom.

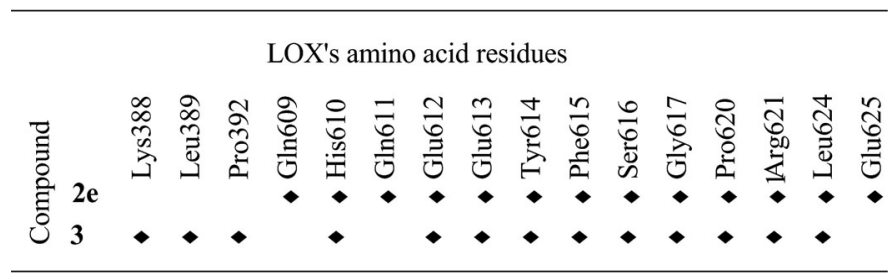




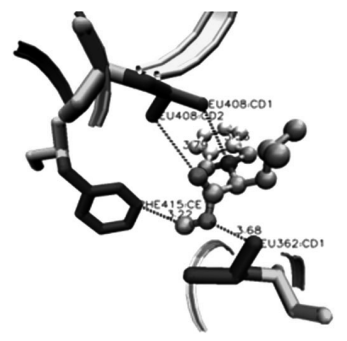

1f

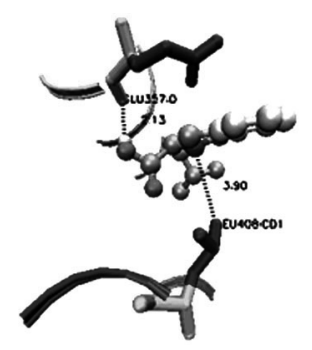

2b
Fig. 5. Docking $\mathbf{1 f}$ and $\mathbf{2 b}$ in active sites of LOX, bond distances are indicated by broken lines.

of $2.73 \AA$ with backbone O of Ser382. The distance between nitrogen of $\mathbf{2 d}$ with backbone $\mathrm{O}$ of Ser 382 is of $2.03 \AA$. The distance of $3.10 \AA$ is observed for $\mathrm{C}=\mathrm{O}$ of $\mathbf{6}$ with backbone $\mathrm{N}$ of Ile383. The $\mathrm{OH}$ group of $2 \mathrm{c}$ exhibits a distance of $2.17 \AA$ with side chain $\mathrm{N}$ of Lys388. Carbonyl group of $\mathbf{5}$ displays a distance of $2.65 \AA$ with side chain N of Lys 388 . The N2 and N1 of 9 show distances of $2.24 \AA$ and $2.43 \AA$, respectively with side chain NZ of Lys388. Carbonyl group of $\mathbf{1 g}$ shows a distance of $2.87 \AA$ with backbone O of Val 391. Nitrogen atom of $\mathbf{1 b}$ exhibits a distance of $3.53 \AA$ with side chain CD1 of Leu 408 . Nitrogen atom of $\mathbf{1 f}$ and $\mathbf{2 b}$ exhibits a distance of 3.73 and $3.90 \AA$, respectively, with side chain CD1 of Leu408 (Fig. 5).

Methyl group of $\mathbf{1 b}$ shows a distance of $3.22 \AA$ from side chain CE1 of Phe415. Carbonyl group of $\mathbf{4}$ shows a distance of $2.61 \AA$ with side chain $\mathrm{N}$ of Gln548 and NH group a distance of $2.51 \AA$ with backbone $\mathrm{N}$ of Val594. The NH of $\mathbf{3}$ shows a distance of $1.71 \AA$ with side chain $\mathrm{C}=\mathrm{O}$ of Glu613. Carbonyl group of $2 \mathrm{e}$ displays a distance of $2.50 \AA$ with backbone $\mathrm{O}$ of Phe615. The NH of $\mathbf{3}$ shows a distance of $1.65 \AA$ with backbone $\mathrm{C}=\mathrm{O}$ of Phe615. The $\mathrm{C}=\mathrm{O}$ group of $\mathbf{3}$ shows a distance of $2.70 \AA$ with backbone $\mathrm{C}=\mathrm{O}$ of Gly617. Carbonyl group of $\mathbf{2 e}$ shows a distance of $2.94 \AA$ with backbone $\mathrm{N}$ of Arg621. The $\mathrm{N}$ atom of $\mathbf{3}$ display a distance of $2.81 \AA$ with side chain $\mathrm{C}=\mathrm{NH}$ of Arg621. Nitrogen atom of 2e displays a distance of $2.88 \AA$ with side chain C of Leu624.

The $\Delta \mathrm{G}$ values were obtained for all the complexes (LOXcompound), among all the complexes, LOX-8 $(-12.76 \mathrm{kcal} /$ mol) resulted to be more stable and from the compounds under study, LOX-1f $(-8.97 \mathrm{kcal} / \mathrm{mol})$ resulted to be more stable. Therefore, the $\Delta \mathrm{G}$ values for $\mathbf{1 b}, \mathbf{1 g}, \mathbf{2 b}, \mathbf{2 e}, \mathbf{2 f}$ and $\mathbf{2 g}$ show to be also stables due to they are almost similar to the value obtained for 7, which is a dual inhibitor. Whereas, theoretical dissociation constant values $K_{d}(\mu \mathrm{M})$ were obtained, among all compounds $8(0.000433 \mu \mathrm{M})$ showed more affinity to LOX, while from compounds under study $\mathbf{1 f}(0.266 \mu \mathrm{M})$ exhibited more affinity to LOX and $\mathbf{1 g}$ exhibits a similar affinity to $\mathbf{7}$. These results show that compounds $\mathbf{1 f}$ and $\mathbf{1 g}$ could be dual inhibitor as compound 7. Table 5 summarizes the $\Delta \mathrm{G}$ and $K_{d}$ values obtained for isoindolines $\mathbf{1}(\mathbf{a - g})$ and $\mathbf{2}(\mathbf{a}-\mathbf{g})$ and compounds 3-9.
Table 5. $\Delta \mathrm{G}(\mathrm{kcal} / \mathrm{mol})$ and $K d(\mu \mathrm{M})$ values for compounds 1 to 9 .

\begin{tabular}{lccccccc}
\hline Compound & $\mathbf{1 a}$ & $\mathbf{1 b}$ & $\mathbf{1 c}$ & $\mathbf{1 d}$ & $\mathbf{1 e}$ & $\mathbf{1 f}$ & $\mathbf{1 g}$ \\
$\Delta \mathrm{G}$ & -6.84 & -8.40 & -6.51 & -7.15 & -7.71 & -8.97 & -8.79 \\
$K_{\mathrm{d}}$ & 9.678 & 0.696 & 16.908 & 5.740 & 2.230 & 0.266 & 0.360 \\
Compound & $\mathbf{2 a}$ & $\mathbf{2 b}$ & $\mathbf{2 c}$ & $\mathbf{2 d}$ & $\mathbf{2 e}$ & $\mathbf{2 f}$ & $\mathbf{2 g}$ \\
$\Delta \mathrm{G}$ & -6.34 & -8.19 & -7.40 & -7.54 & -8.16 & -8.14 & -8.86 \\
$K_{\mathrm{d}}$ & 22.527 & 0.992 & 3.764 & 2.972 & 1.043 & 1.079 & 0.320 \\
Compound & $\mathbf{3}$ & $\mathbf{4}$ & $\mathbf{5}$ & $\mathbf{6}$ & $\mathbf{7}$ & $\mathbf{8}$ & $\mathbf{9}$ \\
$\Delta \mathrm{G}$ & -7.32 & -6.89 & -7.32 & -6.90 & -8.74 & -12.76 & -10.81 \\
$K_{\mathrm{d}}$ & 4.308 & 8.903 & 4.308 & 8.754 & 0.392 & 0.000433 & 0.0119 \\
& & & & & & & \\
\hline
\end{tabular}

\section{Molecular modeling (docking) methodology}

The ligands were drawn using Isis/draw program [42] and converted to three-dimensional format (i.e. pdb) using the WebLab Viewer and Molekel Visualization Package [43,44]. The geometry pre-optimization (molecular mechanic, $\mathrm{MM}+$ ) of the ligands was carried out by using HyperChem- 6 software. The minimum energy structure of the ligands was obtained by means of Density Theory Functions (DFT) calculations at B3LYP/6-31G** level using Gaussian 98 software [45]. To understand the recognition mechanism between LOX enzyme and the ligands, docking simulations were done on the 3-D structure of LOX from rabbit (pdb cod: 1lox [10]. Before starting the docking evaluations, the partial atomic charges (Gasteiger-Marsili formalism), as well as all possible rotable bonds of the ligands and the Kollman charges for all atoms in enzymes were assigned by using the AutoDock Tools 1.4.5 version [46]. Moreover, missing residues were also built and hydrogen atoms were added to the amino acids of the protein with the mentioned program. For docking studies, the AutoDock (3.0.5) was chosen because its algorithm allows full flexibility of small ligands [46]. It has been shown that it successfully reproduces many crystal structure complexes and includes an empirical evaluation of the binding free energy. The preparation of protein and ligand input structures and the definition of the binding sites were carried out under a GRID-based procedure [47]. First, a rectangular grid box were constructed over all protein $\left(126 \times 126 \times 126 \AA^{3}\right)$ with grid points separated by $0.375 \AA$ under blind docking procedure. Previously, the enzyme structures were cleaned of its water molecules and co-crystallized ligands maintaining the haem group. All docking simulations were carried out by using the hybrid Lamarckian Genetic Algorithm, with an initial population of 100 randomly placed individuals and a maximum number of energy evaluations $\left(1.0 \times 10^{7}\right)$. The resulting docked orientations within a root-mean square deviation of $0.5 \AA$ were clustered together. The lowest energy cluster returned by AutoDock for each compound was used for further analysis. All other parameters were maintained at their default settings. All the docking result visualizations were achieved by using a Visual Molecular Dynamics (VMD) program [48].

In conclusion, we describe a theoretical study of two series of isoindolines $\mathbf{1}(\mathbf{a}-\mathbf{g})$ and $\mathbf{2}(\mathbf{a}-\mathbf{g})$ and compounds $\mathbf{3}$ to 
6 as possible LOX inhibitor, which were compared with compounds 7 to 9 taken as reference to find the active sites within LOX. Analysis of the data showed that the compounds investigated exhibit interactions at the same or nearby of amino acid residues within lipoxygenase sites. Due to compounds $\mathbf{1 c}, \mathbf{1 d}$, $1 \mathrm{e}, \mathbf{1 g}, \mathbf{2 c}, \mathbf{2 d}, \mathbf{2 f}, \mathbf{2 g}, \mathbf{5}$ and $\mathbf{6}$ are binding to the LOX at the same region that compounds taken as reference they could be considered as dual inhibitors. Although compounds 1a, 1b, 1f, 2a, 2b and $\mathbf{4}$ are not binding within to LOX exactly at the same region as compounds $\mathbf{7}$ to $\mathbf{9}$, they can be considered as feasible LOX inhibitors due they are in the region of the core of the catalytic domain. Compounds $\mathbf{2 e}$ and $\mathbf{3}$ showed bind to the LOX among amino acids residues near to catalytic iron atom and $\mathbf{3}$ shows also bind in the vicinity of catalytic domain, in consequence they could be inhibitor. On the other hand, distances between several atoms of all compounds with some atoms of amino acid residues were obtained.

\section{Acknowledgments}

Authors thank COFFA, SIP-IPN and for scholarship to K. S.A.C. and also Consejo Nacional de Ciencia y Tecnología (Conacyt- México) for financial support.

\section{References}

1. Morgan, Jr. G. E.; Mikhail, M. S.; Murray M. J. Anestesiología Clínica, 3ed. México, Manual Moderno, 2003, 325-338.

2. Masahide, M.; Rikio, Y. Drug Target Insights. 2008, 3, 137-151.

3. Vane, J. R.; Botting, R. M. Inflamm Res. 1998, 47(suppl. 2), S78S87.

4. Brater, D. C.; Harris, C.; Redfern, J. S.; Gertz, B. J. Am. J. Nephrol. 2001, 21, 1-15

5. Vane, J. R.; Bakhle, Y. S.; Botting, R. M. Annu. Rev. Pharmacol. Toxicol. 1998, 38, 97-120.

6. Parente, L. J. Rheumatol. 2001, 28, 2375-2382.

7. McAdam, B. F.; Castella-Lawson, F.; Mardini, I. A.; Kapoor, S., Lawson, J. A.; FitzGerald, G. A. Proc. Natl. Acad. Sci. USA. 1999, 96, 272-277.

8. Geronikaki, A. A.; Lagunin, A. A.; Hadjipavlou-Lithina, D. I.; Eleftheriou. P.T., Filimonov, D. A., Poroikov, V. V., Alam, I. Saxena, A. K. J. Med. Chem. 2008, 51, 1601-1609.

9. Charlier, C.; Michaux, C. Eur. J. Med. Chem. 2003, 38, 645-659.

10. Gillmor, S. A.; Villaseñor, A.; Fletterick, R.; Sigal, E., Browner, M. F. Nat. Str. Biol. 1997, 4, 1003-1009.

11. Wenzig, E. M.; Oleszek, W.; Stochmal, A.; Kunert, O.; Bauer R. J. Agric. Food. Chem. 2008, 56, 8885-8890.

12. Singh, S.; Khajuria, A.; Taneja, S. C.; Johri, R. K.; Singh, J.; Qazi, G. N. Phytomedicine. 2008, 15, 400-407.

13. Hoshino, T.; Tabuchi, K.; Hirose, Y.; Uemaetomari, I.; Murashita, H.; Tobita, T.; Hara, A. Tohoku J. Exp. Med. 2008, 216, 53-59.

14. Pirillo, A.; Uboldi, P.; Bolego, C.; Hartmut, K.; Catapano, A. L. The Journal of Immonology, 2008, 181, 2821-2830.

15. Yoo, Hyun.; Jeon, B.; Jeon, M-S.; Lee, H.; Kim, T-Y. FEBS Letters 2008, 582, 3249-3253.

16. Mei, G.; Venere, A.; Nicolai, E.; Angelucci, C. B.; Ivanov, I.; Sabatucci, A.; Dainese, E.; Kuhn, H.; Maccarrone, M. Biochemistry 2008, 47, 9234-9242.
17. Claesson, H-E.; Griffiths, W. J.; Brunnström, Ä.; Shain, F.; Andersson, E.; Feltenmark, S.; Johnson, H. A.; Porwit, A.; Sjöberg, J., Björkholm, M. FEBS Journal, 2008, 275, 4222-4234.

18. Maier, T. J.; Tausch, L.; Hoernig, M.; Coste, O.; Schmidt, R.; Angioni, C., Metzner, J., Groesch, S., Pergola, C., Steinhilber, D., Werz, O.; Geisslinger, G. Biochem. Pharmacol. 2008, 76, 862-872.

19. Yong Hwan, Ch.; Hyun, L.; Moon Young, H.; Dae Young, D.; Hyun Pyo, K. J. Med. Food. 2008, 11, 539-543.

20. Celotti, F.; Laufer, S. Pharmacol. Res. 2001, 43, 429-436.

21. Chowdhury, M. A.; Abdellatif, K. R. A.; Dong, Y., Das, D., Suresh, M. R.; Knaus, E. E. Bioorg. Med. Chem. Lett. 2008, 18 , 6138-6141.

22. Zhang, B.; Wang, C. L.; Zhao, W. H.; Lu, M.; Wang, Ch.Y.; Zhong, W. X., Zhou, W. Y., Yu, W. S., Zhang, Y., Li. World J. Gastroenterol. 2008,14, 2494-2500.

23. Horizoe, T.; Nagakura, N.; Chiba, K.; Shirota, H.; Shinoda, M., Numata, H.; Kobayashi, S.; Abe, C. Inflamm. Res. 1999, 48, 432436.

24. Bannwarth, B. Fundam. Clin. Pharmacol. 2004, 18, 125-130.

25. Rotondo, S.; Krauze-Brzósko, K.; Manarini, S.; Evangelista, V.; Cerletti, C. Eur. J. Pharmacol. 2004, 488, 79-83.

26. Rao, P. N. P.; Chen, Q. H.; Knaus, E. E. J. Med. Chem. 2006, 49, $1668-1683$

27. Janusz, J. M.; Young, P. A.; Ridgeway, J. M.; Scherz, M. W.; Enzweiler, K.; Wu, L. I.; Gan, L.; Darolia, R.; Matthews, R. S.; Hennes, D.; Kellstein, D. E.; Green, S. A.; Tulich, J. L.; RosarioJansen, T.; Magrisso, I. J.; Wehmeyer, K. R.; Kuhlenbeck, D. L.; Eichhold, T. H.; Dobson, R. L. M.; Sirko, S. P.; Farmer, R. W. J. Med. Chem. 1998, 41, 1112-1123.

28. Alvaro-Gracia, J. M. Rheumatology 2004, 43(Suppl. 1), i21-i25.

29. Berger, D., Citarella, R., Dutia, M., Grenberger, L. Hallet, W., Poweel, D. J. Med. Chem. 1999, 42, 2145-2161.

30. Cignarella, G.; Sanna, P. J. Med. Chem. 1981, 24, 1003-1010.

31. Sanna, P.; Cignarella, G.; Ananiaa, V.; Siri, R.M. S.; Desole, M. S. Farmaco Ed. Sci. 1985, 40, 777-785.

32. Heidenbluth, K.; Franke, J.; Helga, F.; Toenjes, H.; Schmidt, J. Fr. M. 7732 (CI. A 61K, C 07d), 09 Mar 1970, Appl. 164, 252,27 Aug 1968, 9 pp; Chem. Abstr. 1972, 77, 114241z.

33. Chimenti, F.; Vomero, S.; Farmaco, Ed. Sci. 1975, 30, 884-890, Chem. Abstr. 1976, 84, 43756c.

34. Casagrande, C.; Galli, A.; Ferrini, R.; Miragoli, G. Farmaco [Sci], 1972, 27, 445-470.

35. Carneym, W. J. R.; De Stevens, G., (CIBA LTD.) Ger. Offen. 2.034,240 (CI.CO7d), 28 Jan 1971, US Appl. 18 Jul 1969-25 May 1970, 106 pp. ; Addn. to Ger offen. 1, 913,743 (CA72:1005349q); Chem. Abstr., 1971, 74, 125471.

36. Shuhmann, A.; Tonjes, H.; Schmidt, J. Brit. 989,917 (CI.CO7d), April 22, 1965, Appl. May 15, 1963, 5 pp; Chem. Abstr., 1965, $63,4261$.

37. Dresden, V. A. Belg. 634.852. Oct. 31, 1963, Appl. Jul 11, 1963, 9, 9 pp., Chem. Abstr., 1965, 63, 4261.

38. Mancilla, T.; Carrillo, L.; Zamudio-Rivera, L. S.; Beltrán, H. I., Farfán, N. Org, Prep. Proc. Int. 2001, 33, 341-349.

39. Mancilla, T.; Correa-Basurto, J.; Alavés Carbajal, K. S.; Sánchez Escalante, E. T. J.; Trujillo Ferrara, J. J. Mex. Chem. Soc. 2007, 51, 96-102.

40. Mancilla, T.; Talamás, P.; Díaz, G. J. A.; Correa-Basurto, J.; Alavés Carbajal K. S.; Valle Sandoval, N. Trujillo Ferrara, J. 7th Pan American Regional Symposium. Facultad de Farmacia de la UAEM, México. Cuernavaca, Mor. 8-12, septiembre, 2008.

41. Enzymes, A Practical Introduction to Structure, Mechanism, and data Analysis, Copeland, R. A. Second Edition, 2000, 11-41, Wiley-VCH.

42. ISIS/Draw, MDL Information System, 14600 Catalina Street, San Leandro, CA 94677, USA. The program (Editions of 2.5 and 2.3) is available at the MDL at hhh://www.mdli.com/ 
43. WebLab Viewer, available at http:/www.liv.ac.uk/ctichem/ 16weblab.html

44. Flükiger, P. F., Development of the Molecular Graphics Package MOLEKEL and its Application to Selected Problems in Organic and Organometallic Chemistry, Thèse No 2561, Département de Chimie Physique, Université de Genève, Genève, 1992.

45. Frisch, M. J.; Trucks, G. W.; Schlegel, H.B.; Scuseria, G. E.; Robb, M. A.; Cheeseman, J. R.; Zakrzewski, V. G.; Montgomery, Jr. J. A.; Stratmann, R. E.; Burant, J. C.; Dapprich, S.; Millam, J. M.; Daniels, A. D.; Kudin, K. N.; Strain, M. C.; Farkas, O.; Tomasi, J.; Barone, V.; Cossi, M.; Cammi, R.; Mennucci, B.; Pomelli, C.; Adamo, C.; Clifford, S.; Ochterski, J.; Peterson, G. A.; Ayala, P.Y.; Cui Q.; Morokuma, K.; Malick, D. K.; Rabuck,
A. D.; Raghavachari, K.; Foresman, J. B.; Cioslowski, J.; Ortiz, J. V.; Baboul, A. G.; Stefanov, B. B.; Liu, G.; Liashenko, A.; Piskorz, P.; Komaromi, I., Gomperts, R., Martin, R.L., Fox, D. J., Keith, T.; Al-Laham, M. A.; Peng, C.Y.; Nanayakkara, A.; Challacombe, M., Gill P. M. W., Johnson, B., Chen, W., Wong, M. W., Andres, J.L.; Gonzalez, C.; Head-Gordon, M.; Replogle E. S.; Pople, J. A.; Gaussian 98, Revision A.9, Gaussian, Inc., Pittsburgh, PA 1998.

46. Morris, G. M.; Goodsell, D. S.; Halliday, R. S.; Huey, R.; Hart, W.E.; Belew, R.K.; Olson, A. J. J. Comp. Chem. 1998, 19, 16391662 .

47. Goodford, P. J. J. Med. Chem. 1985, 28, 849-857.

48. Humphrey, W.; Dalke, A.; Schulten K. J. Mol. Graph. 1996, 14, 33-38. 